\title{
АНТИУКРАЇНСЬКА СУТНІСТЬ МОСКВОФІЛЬСЬКОЇ ПРЕСИ У СХІДНІЙ ГАЛИЧИНІ (20-30-ті РОКИ ХХ СТОЛІТТЯ)
}

\author{
Тетяна Слотюк \\ Львівський національний університет імені Івана Франка, \\ вул. Генерала Чупринки, 49, 79044, Львів, Україна \\ e-mail: burdeha@ukr.net
}

У статті розглянуто особливості формування ідейних засад преси традиційного москвофільства після Першої світової війни, вказано на проблематику цієї преси у контексті трансформації москвофільського руху як суспільно-політичного явища.

Ключові слова: москвофільська преса, ідея «единой Руси», українська державність, українська мова, антиукраїнська позиція.

Актуальність дослідження. Ідейні основи москвофільства закладалися ще у XIX столітті, коли лише формувався цей рух. Уже наприкінці століття москвофільство набуло явного антиукраїнського характеру. Ця тенденція ще більше міцніла від початку XX століття, а особливо у 20-30-х роках. У XXI ст. новочасні москвофіли використовують ті ж ідеологеми та гасла, часто завуальовуючи їх і надаючи їм нових форм. Ідея «единства Руси», заперечення української державності, історії, мови, бачення політичного майбутнього у союзі з Росією - це ті ідеї, які пропагували галицькі москвофіли, а сьогодні активно нав’язує російська пропаганда. Критика москвофільства і антиукраїнська сутність його преси на будь-якому етапі українського державотворення завжди залишається важливим і актуальним завданням української науки і публіцистики.

Науково-практична цінність публікації. 3 одного боку, ця публікація доповнить історію українських визвольних змагань та історію українсько-російських взаємин, а з іншого - стане в пригоді під час відповідних інформаційних стратегій у боротьбі з пропагандою «русского мира», у протидії гібридній війні, яку Росія веде проти України.

Аналіз досліджень та публікацій. Вивчення москвофільської преси як явища української історії в контексті історії української журналістики довгий час залишалося поза увагою дослідників. Тому сьогодні є дослідження, присвячені лише окремим виданням москвофільського руху. Л. Сніцарчук у публікації «Москвофільська преса в Галичині міжвоєнного періоду: тематико-типологічні аспекти» дослідила особливості тематики та проблематики цієї преси. І. Михайлин у навчальному посібнику з «Історії української журналістики» відвів вивченню москвофільської преси один із розділів. У 2013 році К. Курилишин видав покажчик «Часопис «Галичанинъ» (Львів, 1893-1913): матеріали до бібліографістики», де подано змістове наповнення

(C) Слотюк Т., 2018 
цього часопису. Повного та грунтовного дослідження цієї проблеми сьогодні немає. Найповніше пресу москвофільського руху поч. XX ст. досліджено у наших публікаціях.

Традиційне москвофільство у XX столітті зазнало значних змін. Це стосується як ідейно-програмних засад, так і мовно-культурного аспекту. Міжвоєнний період був досить складним і в певному сенсі вирішальним для москвофільських організацій, коли поставало принципове питання: «бути чи не бути» взагалі. Суттєвого впливу на ідеологічному рівні москвофіли вже не мали, однак вони все ще залишалися розмінною монетою поміж офіційною Росією та Польщею і Заходом загалом. Росія все ще продовжувала щедро фінансувати Підкарпатську Русь для підтримання вогнища москвофільства, проте такого впливу, який ця група здійснювала у ХІХ столітті, у XX вже не мала. Однак їхн діяльність все ж відігравала значну роль у послабленні національних основ українства. 3 їхньою допомогою Росія прагнула дезактивувати і діяльність т.зв. «мазепинців», які здійснювали вплив не тільки на Заході України, а й на Наддніпрянщині. Російській імперії було замало Східної, Південної і Центральної України, їй хотілося ще й Західної!

«Росія вела війну в ім'я визволення «під’ярмлених» слов'янських народів Австро-Угорщини. У це число входили і «рускіє» 3 Галичини, Буковини і Закарпаття. Ще перед війною російська влада дала притулок деяким галицьким москвофілам, які з вибухом війни створили у Києві «Карпато-русский освободительный комитет» $[1$, c. 106$]$.

Центром відродженого москвофільського руху у Львові у 1918 році стає «Русский исполнительный комитет», керівниками якого були В. Курилович, Д. Марков та члени Комітету К. Черлюнчакевич, М. Третяк і Е. Вальницький. «Русский исполнительный комитет» видавав упродовж двох років (3 кінця грудня 1918 - до кінця грудня 1920 року) газету «Прикарпатская Русь». Це був тижневик, який виходив не тільки російською мовою, а й дублювався латинкою. А з 1 червня 1920 року у формі додатку виходило окреме число цієї газети. Ймовірно, йшлося про те, щоб охопити якнайширші суспільні кола, тому була потреба подавати різнотематичну інформацію.

У своїх національних позиціях й політичних орієнтаціях вони виступали за об'єднання з імперською Росією і, що суттєво, ці москвофіли настільки були засліплені цією орієнтацією, що у їхніх виступах відчутною є віра в Росію і її плани щодо України. «(...) Россія будеть при всъхъ обстоятельствахъ отстаивать автономію всьхъ маленькихъ народовъ, входившихъ прежде въ составъ Россійской Имперіи» [11].

Зі зменшенням політичного впливу одних москвофільських груп, унаслідок розколу виникають інші, тим самим змінюючи пресу та їі ідейно-концептуальні засади. Відтак через антипольську налаштованість газету було заборонено. Натомість під зміненою назвою починає виходити газета «Русь», а з вересня 1922 року, як продовження газети «Русь,» виходить щоденна газета «Жизнь» (видавала «Галицко-Русская Организація»), яка після заборони перебрала на себе політику «Прикарпатской Руси». Отже, газета «Жизнь» почала виходити у Львові 6 вересня 1922 року. Це було не нове видання, а реінкарнована газета «Русь», яку півроку перед тим заборонила польська влада. У вступній статті «От редакціи» часопис засвідчив свою політичну зорієнтованість і накреслив подальший напрям діяльності. Для видавців газети принциповим було питання політичної орієнтації і ставлення до більшовицької Ро- 
ciï. «Особенно жагучим и требующим от нас ясного опредъленія является вопросом нашего отношенія к современной Россіи. Это отношеніе подвергалось за посльднія годы извђстному процессу колебаній, удерживаясь на мертвой точкъ нейтрального невмЂшательства во внутренія дЂла Росіи (...). Может ли подлежать сомнънию, что одной из основной задач русскаго движенія в Галиціи является пропаганда любви к Россіи? А следовательно, если такого сомнънія нът, то, ясное дъло: нашей обязанностью является итти навстрђчу выполненію этой задачи по отношенію к современной совътской Россіи. Ибо это совпадает с линией национальных и социальных интересов нашего народа» [10].

Розв'язання національно-культурного й мовного питання у газеті постає за умови «(..) если бы постаралась (Підкарпатська Русь. $-T$. C.) центр тяжести своей общественной жизни перенести на ч и с т о социальную почву, ръшая национально-языковые вопросы, к а к в т о р о с т е п е н н ы е только культурно-практическим способом, т. е. так, как это дълают незараженные западным націонализмом восточные народы» [21]. Автор пропонує брати приклад зі східних народів, особливо, з грузинського та кавказького, де російська мова панує у всіх сферах життя, але це ніяким чином не заважає розвиватися національним мовам.

Слов'янське питання постає на сторінках газети «Жизнь» у контексті національних проблем малих народів Східної Свропи. Зокрема, це бачимо у публікаціях T. Масарика, які з'явилися на сторінках газети. Як відомо, його бачення вирішення національного питання в Україні мало дуже важливе значення у загальноєвропейському політичному житті. Якщо розглядати це питання вужче, то він не бачив його поза контекстом загальнослов'янським, де українці як нація мають свою унікальну історію і самобутність. Однак, у питанні майбутнього України Т. Масарик стояв на позиціях федерації чи автономії України у складі Росії, інший варіант - самостійність - означав для нього і Чехословаччини загалом німецьку експансію на Схід, а відтак зміцнення пангерманських позицій. Відповідно, він вважав, що «повне державне усамостійнення України спричиниться до повного розколу у лоні Слов'янщини та до послаблення великодержавної сили Росії як головної противаги пангерманської небезпеки для слов'янських народів. А самостійна Україна потрапить під вплив Німеччини, перетвориться на її колонію» [20, с. 24].

Через внутрішні суперечності й різновекторність поглядів щодо майбутньої оріснтації, «Русский исполнительный комитет» 1923 року розколовся і утворилося два табори: ліва партія москвофілів - «Народна воля» і праве крило - Русская народная организация.

Русская народная организация при розколі Российского исполнительного Комитета отримала «у спадок» «Народний Дім» у Львові, «Ставропігійський інститут» $\mathrm{i}$ «Галицько-Руськую матицу». Хоча формальний розкол Русского исполнительного комитета відбувся 1923 року, однак, праве крило москвофілів уже за рік до цього почало видавати газету «Русскій Голосъ». Редакція позиціонувала себе як незалежну політично-економічну газету. Ї̈̈ основною ознакою була «русская идея», яку вони дуже чітко відокремлювали від ідеї комунізму, з яким закликали боротися як із найбільшою інтернаціональною бідою. Засудження більшовизму в Росії за релігійні, мовні, культурні переслідування, безробіття і безкультур'я серед молоді, а головною проблемою, породженою більшовизмом, було, на думку москвофільського автора, те, що: «Единство русской народности разбито. Декретами 
с а н к ц и о н и р о в а н ы с е п а р а т и з м ы (культурно-национальные) малороссовъ и бълороссовъ. На Украинъ и БЪлороссіи идетъ быстрымъ темпом такъ называваемая деруссификація школы и учрежденій, то есть вытьсняется русская культура, прекрасный русский языкъ, въ угоду тамошнымъ самостійникамъ!» [28].

Газета виступала за об’єднання з імперською Росією, і тут у рубриці «Среди газет» друкувалися уривки книги В. Панейка «3’єдинені держави східної Європи, Галичина й Україна супроти Польщі й Росії», де викладені його погляди на непротивлення союзу із Росією. Гострим моментом у цій ситуації є те, що він, як колишній редактор «Діла» і як діяч з іншими переконаннями, змінив свої погляди. Про це пише «Русский Голосъ»: «Панейко доказує, що съ причинъ географическихъ и политическихъ (взагаль нема природной границъ межи «Украиною» и «Московщиною») является необходимостью «восточно-европейский союзъ», в котороิмъ були бы всъ три русски вђтви (велико-мало-бђлорусска) съ остальными народностями Россіи, выключаючи Польшу. Только таке злученье, русская оріентація, могуть злучити всь малоруски земли» [5]. У цій праці В. Панейко дуже гостро виступає проти антиросійської орієнтації і засуджує діяльність т.зв. «сепаратистів» і «українців».

Газета «Русскій Голосъ» продовжила традиційні напади на українську мову [13], не визнавала існування українського народу, а тільки триєдиноіснуючого великоруського. Газета заперечувала саме існування окремої української народності, а тільки підкреслювала свою єдинодушність із Росією і її народом, називаючи себе «русскими». «Чехи во что бы то ни стало стремяться вогнать клинь различья между русскимь народомь и населениемь Прикарпатія. Они хотять доказать и себъ, и другимъ, что Прикарпатцы - это какое-то совершенно особое славянское племя... (...) чехи настаивають на томъ, что населеніе Прикарпатской Руси состоить именно изъ этихъ особ иныхъ, ни на кого другого не похожих «русиновъ» [6]. «(...) идея «самостійной Украины» оставалась и остается чуждой и малопонятной населению Малороссіи» [14].

Своє значення у громадсько-політичному житті Галичини РНО вбачала у боротьбі з українством і усім, що з ним пов'язане: «Мы не можемо забувати на се, що мы не якась тамъ «старорусска умьркована партія», але що русское общество представляе тепер численну могучу масу, въ средъ якои зачинають доперва образоватисъ партіи съ рђжными закрасками, що являеся доказательствомъ жизненности нашего общества... (...) Нема сумніву, що если у насъ счезне рутенство то счезнуть и догматы Р.И.К.» [12].

«Загально извђстно, що приданье слову «Украина» «украинскій» значенья національного и етнографічного символа было вызване хитрою, злостною политикою вороговъ русского народа, пожелавшихъ розьединити его на составни, ворогующи части» [9], - така позиція москвофілів була традиційною і ще раз доводила їхню антиукраїнську спрямованість, а те, що лексеми «Україна» і «український» вони брали в лапки, демонструє несприйняття ідеї державності як такої. «Всђ инакомыслящиि, то есть въ першу чергу мъру мы русскиิ, вважаемся въ очахъ украинофиловъ «зрадниками украинского» народу, и «шкідниками» въ народной работђ. Теперъ пока такъ. Бо передъ воิйной тиि сами панове вважали насъ зрадниками «ясной габсбургской короны», за що намъ по ихъ милости прійшлося заплатити морем кроิви невинных жертв» [7]. Ці ж москвофіли абсолютно відкидали існування української історії поза російською, не приймали до уваги факту існування тисячолітньої української 
культури, що відрізнялися від російської своєю унікальністю і самобутністю. Якщо і згадували про український народ, то тільки в негативно-звинувачувальному тоні, наголошуючи на його «сепаратизмі», а виникнення українського суспільства - це не що інше, як: «малорусске отщепенство сотворили австро-нъмецкиि политики для легшого розбитья русского и славянского свьта (підкр. наше. - T. С.), котрый мавъ статися лишь навозомъ, удобряющимъ и улекшуючимъ германскую экспанзію на всхоิдъ» [7]. Не лише як німецьку колонію описували москвофіли частину «сепаратистської» Галичини, а й називали іï̈ «буферною державою» поміж Польщею і Росією, а в разі об’єднання їхніх політичних зусиль, це могла бути Галичина, приєднана до Польщі на умовах федерації [4]. «Банкрутство» української ідеї газета обговорювала, посилаючись на те, що Київ на той час був повністю русифікованим, і навіть ті поляки, які приїздили до Києва 3 надією «повправлятися» в українській мові, не мали для цього україномовних співрозмовників [18].

Для москвофілів Східної Галичини вирішальним у політичному сенсі став березень 1924 року. Саме тоді відбулися вибори в Карпатській Русі (Ужгороді) до парламенту, на яких вони здобули тільки два представничі мандати. Це вже остаточно означало смерть політичного впливу москвофілів у суспільстві, повну недовіру до них як представників суспільних інтересів русинів. «Для пражского-же праивтельства выборы являются грозным «memento», чтобы окончательно прекратило противонародную и протирусскую политику по отношению Карпатской Руси, а стало на искренно славянскую точку зрђнія, а не надЂясь на «самостійну» Украину, под вліяніемъ разныхъ бывшихъ австрийскихъ патріотовъ Галицкой «Вкраіны», угаждать тъмъ противославянскимъ элементамъ, измънникамъ родного народа и вводить насильственно на Карпатской Руси украинизацію» [3]. Газета закликала чеське керівництво прислухатися до голосу карпатського народу і взятися за поборництво усього українського, а відтак протистояти комунізму. На початку квітня 1924 року під час виступу в чеському парламенті москвофіл А. Гагатко заявляв про необхідність проведення земельної реформи, розв'язання культурного питання, яке, на його переконання, мало відбутися згідно із традиціями, закладеними в народному житті. Він також просив, аби у школі не було політичної агітації. «Карпаторусскій народъ считаеть себя неразрывной частью единаго русского народа, с о х р а н я е т своенарьчіе и защищаеть свою мъстнуюкультуру, останет ся навсегда за культурнымъ единствомь съ остальнымъ русскимь народомь и не можеть отказаться от языка Пушкина, Го го ля, Т ур ге н ев а и Д о с т о е в ск а го» [15]. Інший москвофіл, М. Мікласький, читаючи одну із лекцій, зауважив: «политическое единство не всегда бываетъ обязательным условіемъ къ образованію одного народа» [27].

У 1926 році починає виходити відновлена газета «Голосъ Народа», як орган відновленого 1921 року «Рольничого Союзу», але фінансував цю газету т. зв. комісар «Народного Дому» Л. Черкавський. «Русскій Голось» відразу ж накинувся на редакцію газети за сприяння розколу серед «галицких русских», застерігаючи від нової форми рутенства [19].

Газета «Русскій Голось» подає резолюцію з'їзду Русской народной организации, який відбувся на початку липня 1926 року. Учасники з'їзду виступали проти закриття православних церков, вимагали повернення сільського (громадського) са- 
моуправління, а також - визнати Галицьку Русь «принадлежащей кь малорусской вЊтви великого русского народа» [17].

1928-й рік - час виборів до польського сейму. Москвофіли отримали всього один мандат. В. Каренін закликав до самоорганізації задля втілення «русской идеи». Вирішення майбутнього галицьких українців відбувається, на думку газети, досить неоднозначно і гарячково: «польская политика, развиваясь в области неестественных устремлений, очутилась в заколдовном кругу противорьчій и в каком-то словно безвыходном тупикъ, гдњ и наш маленький гал.-русскій вопрос рђшается в горячкњ руссофобіи и царебоязни» [23].

Українство і самостійність України газета подавала як «денаціоналізацію», як найбільшу загрозу для остаточного об’єднання з Росією. «Украинство» и «самостійничество», как посльдняя ступень на пути к денационализаціи (...) «украинское пораженіе является сльдствіем не столько польской силы, сколько «украинской» неустойчивости. Украинство - это компромисс, русское соглашательство и непротивленіе чужому засилью (...). И на самом деле на наших глазах в Галичинъ происходит процес вырожденія «украинства» в посную денационализацію» [25]. Автор цих рядків (В. Каренін) вважає, що саме українство стало причиною культурної полонізації і російської денаціоналізації в Галичині, а самостійницькі позиції тільки роблять шкоду культурному й суспільному життю краю.

Тоді ж, 1928 року, з'являється нова газета - «Земля і Воля». Називали себе незалежною радикальною хлопською газетою. Це був орган РНО і соціал-демократичної партії, лівого крила москвофілів. I якщо спочатку, у перших числах видання, тут прочитувалася орієнтація на старорусинів і підтримання давніх церковних традицій, то вже у другій половині 1928 року (приміром у ч. 36 від 23 вересня) вже бачимо захист політики Радянської Росії і гостру критику прихильників С. Петлюри та УНДО. Також простежується особливо виразна та гостра антипольська політика. Серед основних тем, які порушувала газета: обробіток землі і збір урожаю, серед постійних рубрик: «Кооперація (історія, теорія, практика)», листи з регіону, «Що в світі чувати?» (ця рубрика традиційно починалася з повідомлень з Совєтської Росії), особливу увагу приділяла газета тим, що свого часу були інтерновані в таборі біля Талергофа (щоправда, серед них були не лише москвофіли).

На загальному галицько-руському політичному з’ізді 6 червня 1928 року було створено «Русскую Селянскую Организацию» (РСО), яка мала укріпити позиції проросійської політики серед галичан. Однак, вже 1929 року від цієї організації відкололася «Русская Аграрная Партия». І якщо газета «Русскій Голос» вітала це новоутворення (йдеться про РСО) як зміцнення «русскаго народнаго движенія» [8], то у газеті «Пролом» (№ 2 (3) від 15 травня 1934 р.) було визначено місце і значення москвофілів у такому формулюванні: «У нинішніх провідників РСО, тої політично-націонільної орієнтації, що намагається стати спадкоємцем колишніх т. зв. староруських чи москвофільських орієнтацій, не добачуємо ані зрозуміння ясної очевидної сучасної дійсности, ані тим менше спроби створити яку-небудь орієнтацію приноровлену до тої дійсности (...). Словом, практична діяльність РСО б’є дійсно по голові його політичну деклямацію, гонить тих політичних трупів назад там, де їм місце: у могили...».

У 1930 році газета «Русскій Голосъ» опублікувала нарис А. Камінського «Историческая стоимось народников и общерусов». Автор публікації вважає, що зміцненню польського імперіалізму служить український «сепаратизм», «самостійна 
Украина - это капитал для Запада, а руина для Руси и - в окончательном итоге - для Польши» [22].

Ще одне принципове питання, порушене А. Камінським, - з'ясування причин, 3 яких поляки підтримували самостійницькі потуги галицьких українців. Він пояснює це тим, що була негласна угода між поляками та українцями про нейтралізацію неприємних для поляків москвофілів, тим самим мінімізуючи опір галичан в імперських наступах Польщі.

Газета передруковувала на своїх сторінках публікації із газети «Россія и Славянство» про книгу І. Лаппо «Идея единства русскаго народа в Юго-Западной Руси в епоху присоединенія Малороссіи к Московскому государству» (Прага, 1929 р.). Автор розвідки постає як високопрофесійний історик із європейським ім'ям, який написав істинну історію Росії, на відміну від вигаданої деякими українськими істориками, як зазначається у статті (малося на увазі М. Грушевського). Серед дискусійних фактів, поданих I. Лаппо, привертає увагу те, що він пише про Київську Русь, як про «кіевсксій період русской исторіи» (підкр. наше. - T. С.) [26]. Це не перша праця, де I. Лаппо намагався знайти пояснення співпраці українських самостійників iз поляками. У праці «Происходженіе украинской идеологіи новъйшаго времени» автор називає «українство» нічим іншим, як однією із течій південноросійської інтелігенції. Не більше і не менше, тільки течією, не народністю, виокремлює не історично зумовлену і традиційно сформовану націю, а тільки течію.

У 1930 році позиція газети «Русскій Голосъ» ставала дедалі ворожішою до самостійницьких настроїв у Галичині. Прихильників самостійної України звинувачували в запроданстві, зраді «русской» ідеї та безпринципності. Автори публікацій дуже послідовно і систематично обговорювали ці суспільно-політичні процеси, кажучи про штучність творення української державності, засуджуючи «самостійників» за начебто притаманний їм лозунг: «со всђми и против всъх». Йшлося про те, що будьяка політична конфігурація, яку підтримують українці і яка суперечить інтересам Росії, є антинародною і, що більш важливо, - антиросійською. Державницькі настрої галицьких українців, заперечення єдності з Росією означало втрату для москвофілів шансів на поширення панрусизму далі на Захід. Що стосується загалом української iсторії, то найбільші нападки були на М. Грушевського. Він поставав на сторінках газети, як той, хто штучно створив українську націю. Москвофільські публіцисти звинувачували українців у тому, що ті намагалися використати і поляків, і більшовиків, обдурюючи, зрештою, і перших, і других. «В общественной жизни українство стремится создать какой то призрак національной идеи, но не имъя моральних сил для этого, падает в сторону имперыализма, либо московскаго, либо римскаго» [2].

Щодо зовнішньої політики, то «Русскій голосъ» підкреслював тільки умовність підтримки німцями самостійницьких настроїв українців, оскільки це мало загрозу протиставити собі Польщу і Росію, а що гірше - підштовхнути їх до об’єднання. Тому Німеччина тільки умовно підтримувала українців, щоб, у разі потреби, використати їх у серйозному конфлікті із Польщею, якщо не вдасться зберегти курс на зближення, здійснюючи таким чином тиск на Росію. «Самостійничество, как серьезное орудіе против Россіи, играет нынъ нъкоторую роль в руках польских имперіалистов» [16].

Мовне питання для газети теж залишалося принциповим. Що цікаво, В. Каренін, автор численних публікацій, які стосувалися саме галицьких українців і їхнього 
історичного минулого/майбутнього, писав про галицьких «русских» як про тих, хто не здійснив своєї історичної місії. Вони, за словами Кареніна, не навчили галичан російської літературної мови, а створили своє «язичіє». Отже, можна припустити, що тогочасні москвофіли не признавали своєї приналежності до давніх москвофілів, які створили «язичіє». Закиди щодо неосвіченості і неспроможності дати народові одну літературну мову стосувалися і «сепаратистів», які хоч і створили свою мову, але не зробили нічого для того, щоб вона стала загальновживаною і загальнозрозумілою. «Таким образом в Галичинь возникли два непригодных в жизни суррогаты язика, но нет языка в настоящем значении этого слова» [24]. Каренін звернув увагу і на впливи польської, угорської, чеської, словацької і румунської мов на українську зокрема, що у майбутньому суттєво вплине на усамостійнення і неуподібнення української мови до російської. «ВЊковое вліяніе на малорусскій язик польскаго языка и систематичная порча его сепаратистами в теченіе нъскольких десятков льт привели к тому, что между малорусским и русским язиками есть уже не только природная разница в выговоре, но и искусственная разница в словарђ. Ныне малорусскій язык страдает полонизмами и несуразными новообразованіями, придуманными сепаратистами, чтобы уничтожить характер (підкр. наше. - T. C.) малорусскаго языка» [24].

Висновки. Москвофіли в політичному житті Галичини після Першої світової війни значно втратили свої позиції. Формування політичного порядку денного відбувалося за участі все меншої кількості представників від москвофільської партії. Із року в рік, через різновекторність поглядів і численні розколи в середовищі москвофілів, ця політична група втрачала свої позиції у суспільно-політичному та громадському житті Галичини. Відтак преса цього руху зазнавала значних трансформацій. Ідейні основи москвофільства виживали себе, втрачаючи зв'язок з реальністю.

Розв'язання «українського питання» для москвофілів полягало у повній відірваності від Заходу, цьому сприяла й антипольська позиція та орієнтація на Росію, яка щедро фінансувала підтримання цього антиєвропейського вогнища на заході України. Питання історії не розглядалося поза контекстом російської минувшини, мовне питання полягало в запереченні існування загалом української мови як такої, а релігійне життя для москвофілів можливе було лише за існування і панування православної церкви.

\section{СПИСОК ВИКОРИСТАНОЇ ЛІТЕРАТУРИ}

1. Грицак Я. Нарис історії України: Формування української модерної нації / Ярослав Грицак: [ навч. посіб.]. - К.: Генеза, 1996. - 360 с.

2. [Без автора] Без правды / [Без автора] // Русскій голосъ. - № 14 (408). - 1930. 23 лют.

3. [Без автора] Выборы въ Карпатской Руси / [Без автора] // Русскій голосъ. - № 8. 1924. - 31 берез.

4. [Без автора] Въ защиту правъ русской национальности (Речь депутата Н. С. Серебреникова, произнесенная 10 іюля въ Сейм во время дискуссіи надь языковыми законами) / [Без автора] // Русскій голосъ. - № 21. - 1924. - 23 лип.

5. [Без автора] Идея «самостійной» Украины - плодь австрыйскыхь штыковь / [Без автора] // Русскій голось. - №12 (16). - 1922. - 3 верес. 
6. [Без автора] Изъ жизни Подкарпатской Руси. Русскіе или Русины? / [Без автора] // Русскій голосъ. - № 23. - 1922. - 9 груд. (26 лист.).

7. [Без автора] Мало горя / [Без автора] // Русскій голосъ. - № 31. - 1923. - 11 серп. (29 лип.).

8. [Без автора] На порогъ новаго года / [Без автора] // Русскій голосъ. - № 1 (293). 1929. - 2 січ.

9. [Без автора] Не учать уже русского языка / [Без автора] // Русскій голосъ. - № 6. 1923. - 10 лют. (28 січ.).

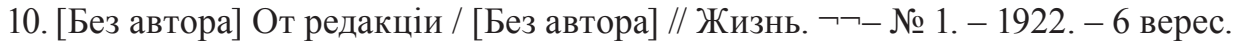

11. [Без автора] Противъ тренований поляковъ / [Без автора] // Прикарпатская Русь. № 56. $-1920 .-9$ квіт.

12. [Без автора] Прочъ с рутенством / [Без автора] // Русскій голосъ. - № 3. - 1922. 15 (2) лип.

13. [Без автора] Рідна мова / [Без автора] // Русскій голось. - № 12. - 1922. - 16 верес.

14. [Без автора] Роздувайте іскру въ огонь / [Без автора] // Русскій голосъ. - № 27. 1923. - 1 (14) лип.

15. [Без автора] Русское слово въ чешском парламенть // Русскій голосъ. - № 10. 1924. - 20 квіт.

16. [Без автора] Ставка на самостійничество (Во внутренней политике). Продолженіе / [Без автора] // Русскій голосъ. - 1930. - 6 квіт.

17. [Без автора] Сьђздь Русской Народной Организаціи / [Без автора] // Русскій голосъ. - № 163. - 1926. - 11 лип.

18. [Без автора] Украина без украинцъвъ / [Без автора] // Русскій голосъ. - № 11. 1923. - 17 (4) берез.

19. [Без автора] Чи знову рутенство? / [Без автора] // Русскій голосъ. - № 162. - 1926. 4 лип.

20. Віднянський С. В. Українське питання в поглядах Т. Г. Масарика та політиці першої Чехословацької республіки / С. В. Віднянський // Матер. Першої українсько-чеської наук.-практ. конф. «Масариківські читання» : Т. Г. Масарик і нова Європа (м. Київ, 7-8 квітня 1998 р.) / відп. ред. С. В. Віднянський. - К., 1998. -80 с.

21. Г. Подкарпатская Русь / Г. // Жизнь. - № 30. - 1923. - 25 квіт.

22. Каминский А. Историческая стоимость народников и общерусов / Андрей Каминскій // Русскій голосъ. - № 18 (412). - 1930. - 8 берез.

23. Каренин В. В горячке руссофобіи / В. Каренин // Русскій голосъ. - № 264. - 1928. 22 лип.

24. Каренин В. К вопросу о язикъ / В. Каренин // Русскій голосъ. - № 1 (395). - 1930. 2 січ.

25. Каренин В. На путях к денаціонализаціи / В. Каренин // Русскій голосъ. - № 279. 1928. - 21 жовт.

26. Львов Л. О малорос. идеологіи / Лоллій Львов // Русскій голосъ. - № 6. - 1930. 23 січ.

27. Микласкій М. Русъ и Украина / Микласкій М. // Русскій голосъ. - № 31. - 1924. 7 груд.

28. Н. К. Д. Почему мы - враги большевизма? / Н. К. Д. // Русскій голосъ. - № 29. 1923. - 15 (28) лип. 


\title{
ANTI-UKRAINIAN ESSENCE OF THE RUSSOPHILE PRESS IN THE EASTERN GALICIA (20-30 YEARS OF THE 20 ${ }^{\mathrm{TH}}$ CENTURY)
}

\author{
Tetiana Slotiuk \\ Ivan Franko National University of Lviv, \\ Generala Chuprynky Str., 49, 79044, Lviv, Ukraine \\ e-mail:burdeha@ukr.net
}

The main idea of this article is the fact that Russophile movement was losing its influence in public-political life of Galicia at the beginning of 20th century after World War I; however it was still financed by Moscow. In postwar Galicia Russophile camp split and it significantly influenced the functioning of the press of this movement. Russophile organizations undergo a split, thereby dividing the press.

After war the Russian Revolutionary Committee, headed by V. Kurilovich and D. Markov, became the center of the revived Russophile movement in Lviv in 1918. The same Committee published the newspaper «Prykarpatskaya Rus'». In its national positions and political orientations, the newspaper advocated unification with Russia, however, the newspaper was banned for its anti-Polish policy. Instead, the newspaper «Rus'» begins its publishing under the changed name. In 1922, as a continuation of the newspaper «Rus'», a daily newspaper «Zhyzn'» is published (it was published by the Galician-Russian Organization), which took over the policy of «Prykarpatskaya Rus» after its prohibition.

The article deals with the question of the split in the Russophile environment and refers to the features of the transformation of the press of this political group. Due to internal contradictions and different-sided views on future orientation, the Russian Executive Committee of 1923 splits up and sets up two camps: left party of Muscovites - «Narodnaya Volya» («People’s Will») and right one - Russkaya Narodnaya Organizatsiya (Russian People's Organization). Since 1922, the year before the official split, the same organization began publishing the newspaper «Russkiy Golos» («Russian Gaul»). The editorial office declared itself as an independent political and economic newspaper. The main focus was the dependence on the «Russian idea», which they were very clearly separated from the ideas of communism, which they were called to fight with, as the greatest international misfortune.

The main feature of this press is the denial of the existence of Ukrainian language, literature, history, state and the right to self-determination in relation to its future. Traditional Russophile movement saw the future of the Galician Rusyns in unity with Moscow. The strength of the Russophiles weakened on the political arena of Galicia, so their attitude toward Ukrainians became more aggressive and anti-Ukrainian.

Key words: Russophiles press, Russian idea, Ukrainian state, Ukrainian language, antiUkrainian position. 